\section{O timbre \\ pós-moderno \\ da Voz}

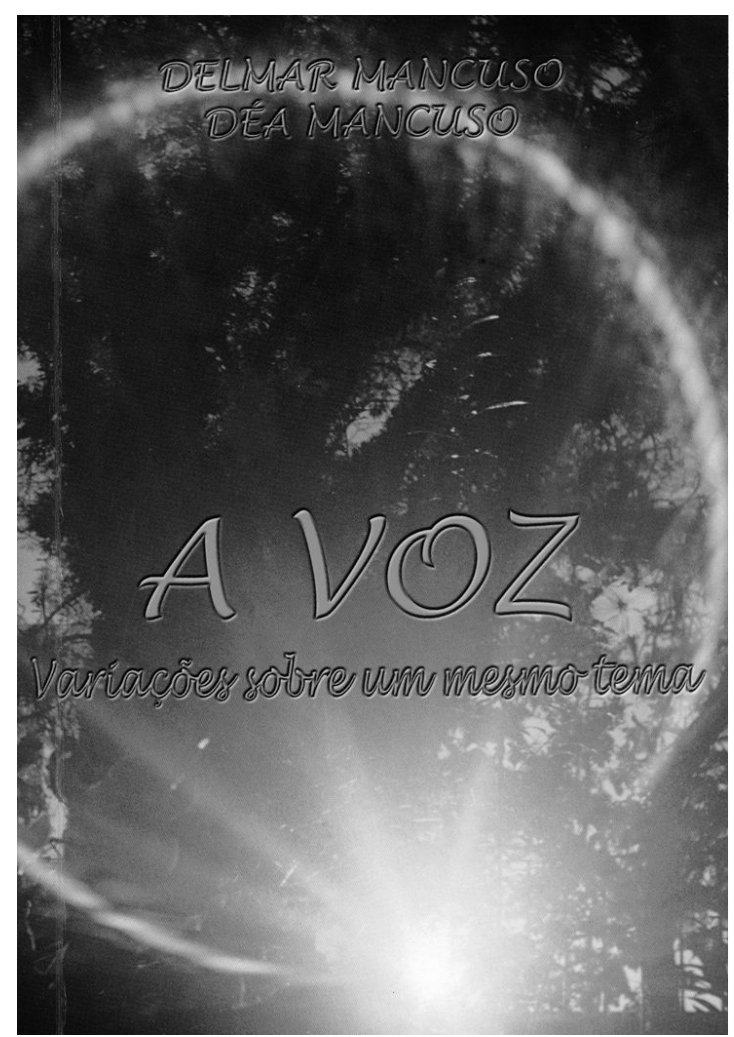

\section{Roberto Ramos}

Prof. Progr. Pós-graduação da FAMECOS/PUCRS
O LIVRO, A Voz: Variações sobre um mesmo Tema, de Delmar Mancuso e Déa Mancuso, da Editora O Quintal, é um timbre de sensibilidade. Abraça, com os seus significantes, o significante Voz em sua inflexão pósmoderna.

O verde da capa pluraliza significações. Simboliza a esperança, suprema tese do senso comum, embalando um esperar para o dia seguinte da vida. Também emblematiza a sabedoria do simples da natureza, que se ambientaliza em árvores, flores e jardins, reeditando o quintal.

Há uma simbiose do verde, com um círculo dourado - grifo de totalidade diagramando a finitude do infinito da natureza. É o significante, derramando a água de poço de uma sensibilidade, com sabor de terra.

O significante capa sintetiza, em sua vertente, as gotas poéticas, que jorram nas 241 páginas seguintes. Condensa, barrocamente, um estilo pós-moderno de pronunciar a invariância da Voz no ritual quotidiano do viver, com vida.

O livro abdica de qualquer postura metodológica. Aí, estabelece o seu comprometimento com o método, não-nomeado, mas confessado na máscara de sua implicitude.

O método se desnuda em sua multidisciplinaridade. Canta a Voz em um jogral divino, vestido de religiosidade. Diz a Voz, em um sentido psicanalítico, como sumário dos cochichos do Inconsciente. Eis o perfil de sua invariância, decodificada pela sonoridade da multidisciplinaridade.

A Voz é o regresso aos recantos dos jardins da fase oral, onde a primeira infância floresce, ao alvorecer da vida. É a configuração da gênese, com a fisionomia do arcaico, anotado a priori na capa pelos traços da natureza, decorada pela palavra, com sotaque de poesia. 
Na ribalta quotidiana, alicerçada pela tecnologia do dia e da hora, os autores encenam uma contra-hegemonia. Valorizam a decupação da palavra, com um halo de criatividade, ícone de universo artístico, cantado em verso e decantado no pomar da sensibilidade.

O sociólogo francês Michel Maffesoli em seu livro No Fundo das Aparências (Petrópolis: Vozes, 1996), categoriza a pós-modernidade como a simbiose do arcaico com o desenvolvimento tecnológico, envolta pelo estilo barroco.

Portanto, o livro, A Voz: Variações sobre um mesmo Tema, dos irmãos Mancuso, conjuga o arcaico e o desenvolvimento tecnológico, com uma pronúncia barroca. É um hino poético à $\mathrm{Voz}$, com seu timbre pósmoderno 